D. Konrad, M. Haney, G. Johansson, M. Wanecek, E. Weitzberg and A. Oldner Am J Physiol Heart Circ Physiol 293:988-996, 2007. First published Mar 30, 2007; doi:10.1152/ajpheart.01023.2006

You might find this additional information useful...

This article cites 65 articles, 21 of which you can access free at: http://ajpheart.physiology.org/cgi/content/full/293/2/H988\#BIBL

Updated information and services including high-resolution figures, can be found at: http://ajpheart.physiology.org/cgi/content/full/293/2/H988

Additional material and information about AJP - Heart and Circulatory Physiology can be found at: http://www.the-aps.org/publications/ajpheart

This information is current as of August 21, 2007.

AJP - Heart and Circulatory Physiology publishes original investigations on the physiology of the heart, blood vessels, and lymphatics, including experimental and theoretical studies of cardiovascular function at all levels of organization ranging from the intact animal to the cellular, subcellular, and molecular levels. It is published 12 times a year (monthly) by the American

Physiological Society, 9650 Rockville Pike, Bethesda MD 20814-3991. Copyright @ 2005 by the American Physiological Society. ISSN: 0363-6135, ESSN: 1522-1539. Visit our website at http://www.the-aps.org/. 


\title{
Cardiac effects of endothelin receptor antagonism in endotoxemic pigs
}

\author{
D. Konrad, ${ }^{1}$ M. Haney, ${ }^{2}$ G. Johansson, ${ }^{2}$ M. Wanecek, ${ }^{1}$ E. Weitzberg, ${ }^{1}$ and A. Oldner ${ }^{1}$ \\ ${ }^{1}$ Department of Physiology and Pharmacology, Section for Anaesthesiology and Intensive \\ Care, Karolinska Institute, Stockholm, Sweden; and ${ }^{2}$ Perioperative and Surgical Sciences, \\ Anesthesiology and Intensive Care Medicine, Umeå University, Umeå, Sweden
}

Submitted 19 September 2006; accepted in final form 30 March 2007

Konrad D, Haney M, Johansson G, Wanecek M, Weitzberg E, Oldner A. Cardiac effects of endothelin receptor antagonism in endotoxemic pigs. Am J Physiol Heart Circ Physiol 293: H988-H996, 2007. First published March 30, 2007; doi:10.1152/ajpheart.01023.2006.Myocardial depression in sepsis is frequently encountered clinically and contributes to morbidity and mortality. Increased plasma levels of endothelin-1 (ET-1) have been described in septic shock, and previous reports have shown beneficial effects on cardiovascular performance and survival in septic models using ET receptor antagonists. The aim of the current study was to investigate specific cardiac effects of ET receptor antagonism in endotoxicosis. Sixteen domestic pigs were anesthetized and subjected to endotoxin for $5 \mathrm{~h}$. Eight of these pigs were given tezosentan (dual ET receptor antagonist) after $3 \mathrm{~h}$. Cardiac effects were evaluated using the left ventricular (LV) pressure-volume relationship. Endotoxin was not associated with any effects on parameters of LV contractile function [end-systolic elastance (Ees), preload recruitable stroke work (PRSW), power $_{\text {max }} /$ end-diastolic volume $\left(\mathrm{PWR}_{\max } / \mathrm{EDV}\right)$ and $\mathrm{dP} / \mathrm{d} t_{\max } /$ end-diastolic volume $\left(\mathrm{dP} / \mathrm{d} t_{\max } /\right.$ EDV)] but with impairments in isovolumic relaxation (time constant for pressure decay, tau) and mechanical efficiency. Tezosentan administration decreased Ees, $\mathrm{PWR}_{\max } / \mathrm{EDV}$, and $\mathrm{dP} / \mathrm{d} t_{\max } / \mathrm{EDV}$, while improving tau and LV stiffness. Thus, dual ET receptor antagonism was associated with a decline in contractile function but, in contrast, improved diastolic function. Positive hemodynamic effects from ET receptor antagonism in acute endotoxemia may be due to changes in cardiac load and enhanced diastolic function rather than improved contractile function.

sepsis; endotoxin; inotropy; end-systolic elastance; diastolic

SEPTIC MYOCARDIAL DEPRESSION is a dire manifestation of sepsis, enhancing mortality in an already devastating disease (13). Diastolic and systolic dysfunction have been described (40, 45, 48) as potentially causing deterioration of both right and left ventricular function $(42,44)$. The causative mechanisms are far from clear, although a number of cytokines and nitric oxide have been proposed and investigated (31, and references therein). The endothelins (ETs), also proposed in this context, are a family of peptides with powerful vasoactive properties first described in 1988 (64). Endothelin-1 (ET-1), which is probably the most important of the ETs, as far as cardiovascular effects in humans are concerned, is mainly produced by the vascular endothelium and acts on two groups of receptors: $\mathrm{ET}_{\mathrm{A}}$ and $\mathrm{ET}_{\mathrm{B}}$ receptors, which are located on vascular smooth muscle cells, mediating contraction. The $\mathrm{ET}_{\mathrm{B}}$ receptor is also found in the endothelium, mediating vasodilation by release of nitric oxide or prostacycline $(15,17)$.

In the heart, the predominant ET isopeptide is ET-1 (47), and both $\mathrm{ET}_{\mathrm{A}}$ and $\mathrm{ET}_{\mathrm{B}}$ receptors are found in the myocar-

Address for reprint requests and other correspondence: D. Konrad, Dept. of Anaesthesiology and Intensive care, Karolinska Hospital, SE17176 Stockholm, Sweden (e-mail: david.konrad@ki.se). dium, endocardium, conducting system, and coronary vessels $(4,39)$. The ET system and ET-1 binding properties on cardiomyocytes are largely similar in pigs and humans (38).

The ET system is involved in the cardiovascular response to several disease processes. Increased plasma levels of ET-1 have been noted in association with acute myocardial infarction, congestive heart failure, pulmonary hypertension, and septic shock (59). In human sepsis, ET-1 plasma levels are increased fivefold (61) and correlates to severity of illness, as well as outcome (7). Previous reports, including those from our own group, have shown positive cardiovascular effects using ET-receptor antagonists in septic settings $(10,29,43,56)$. However, none of these studies was designed to evaluate specific cardiac effects, and the positive results seen may merely constitute alterations in cardiac preor afterload. Interestingly, other investigators have reported conflicting inotropic effects of ET-1 in normal vs. pathological conditions $(33,53)$. By analogy, we were recently able to demonstrate positive inotropic effects of intracoronary administration of ET-1 in normal, anesthetized pigs (30).

The aim of the present study was to investigate the cardiac effects of ET-receptor antagonism in endotoxemic pigs. Left ventricular (LV) pressure-volume relations (LVPVR) were examined by means of conductance volumetry in an in vivo model of porcine endotoxemia. On the basis of our previous results, we postulated that dual ET-1 receptor antagonism by administration of tezosentan would improve myocardial contractile and diastolic function in a septic state.

\section{MATERIALS AND METHODS}

The Research Ethical Committee at Umeå University approved the experimental protocol for this study, which was conducted in conformity with the European Convention for the protection of vertebrate animals used for experimentation and other scientific purposes (Council of Europe No. 123, Strasbourg, 1985) and with the Guide for the Care and Use of Laboratory Animals (National Institutes of Health, 1996).

Sixteen female domestic land race pigs weighing between 38 and $55 \mathrm{~kg}$ were anesthetized after fasting overnight with free access to water. After intramuscular injections of ketamine $10 \mathrm{mg} / \mathrm{kg}$, azaperone $4 \mathrm{mg} / \mathrm{kg}$, and atropine $50 \mu \mathrm{g} / \mathrm{kg}$, anesthesia was induced with pentobarbital sodium $12 \mathrm{mg} / \mathrm{kg}$ iv and maintained by a continuous infusion of pentobarbital sodium $5 \mathrm{mg} \cdot \mathrm{kg}^{-1} \cdot \mathrm{h}^{-1}$, midazolam 0.3 $\mathrm{mg} \cdot \mathrm{kg}^{-1} \cdot \mathrm{h}^{-1}$ and fentanyl $20 \mu \mathrm{g} \cdot \mathrm{kg}^{-1} \cdot \mathrm{h}^{-1}$. Intravenous fluids were administered as Ringer acetate at a rate of $20 \mathrm{ml} \cdot \mathrm{kg}^{-1} \cdot \mathrm{h}^{-1}$ throughout the study period. After tracheotomy, the animals were mechanically ventilated (Evita 4 ventilator; Draeger Medical, Lubeck,

The costs of publication of this article were defrayed in part by the payment of page charges. The article must therefore be hereby marked "advertisement" in accordance with 18 U.S.C. Section 1734 solely to indicate this fact. 
Germany) with an $\mathrm{FI}_{\mathrm{O}_{2}}$ of 0.4 , peak end-expiratory pressure of 5 $\mathrm{cmH}_{2} \mathrm{O}$ (Artema; Artema Medical, Stockholm, Sweden) with tidal volumes less than $10 \mathrm{ml} / \mathrm{kg}$. If arterial oxygen tension $\left(\mathrm{Pa}_{\mathrm{O}_{2}}\right)$ dropped below $6.5 \mathrm{kPa}, \mathrm{FI}_{\mathrm{O}_{2}}$ was increased with increments of 0.10 . Blood gas measurements were performed hourly (ABL 5, Radiometer, Copenhagen, Denmark). Body temperature was measured and maintained between $38^{\circ}$ and $39^{\circ} \mathrm{C}$ with the help of heating pads and a warming blanket.

All vascular catheters were placed through direct cutdowns onto the jugular or carotid vessels. A three-lumen central venous catheter (Arrow International, Reading, PA) and a thermistor-tipped pulmonary artery catheter (Optimetrix, Abbott, IL) were placed. An arterial catheter was placed with the tip in the descending aorta. A 7.5 French (Fr) balloon occlusion catheter (Vascular Technologies, Solna, Sweden) was positioned in the inferior vena cava directly adjacent to the right atrium to provide a controlled transient restriction of venous return. Arterial, central venous, and pulmonary artery pressures were measured using a fluid-filled catheter system and transducers (Gabarith PMSET, Becton Dickinson, Franklin Lakes, NJ). A 7 Fr left ventricular (LV) pigtail combination tip manometer and conductance catheter (CA-71083-PN; CD Leycom, Zoetermeer, Holland) was placed through an 8.5 Fr introducer in the carotid artery system into the left ventricle using fluoroscopic guidance. A dual thermistortipped coronary sinus catheter (Webster, CA) was placed in the great cardiac vein. Catheter position was checked and rechecked using fluoroscopy, and minimal amounts of intravascular radiographic contrast (Visipaque; Amersham, Solna, Sweden). An intravenous heparin infusion, 1,000 IE per hour, was started when the cardiac catheters were in place to minimize the risk of catheter-related thrombosis. At termination of the experiment, the pigs were euthanized using a combination of pentobarbital sodium bolus intravenously followed by a bolus of potassium intravenously.

Measurements and calculations. The conductance volumetry technique is well described elsewhere (52) and we have previously described this method in depth $(8,21)$. LV volume was measured using the 12-electrode dual-field conductance catheter with $8-\mathrm{mm}$ spacing between electrodes, and a signal conditioning-amplifier (Leycom Sigma 5DF, Cardiodynamics, Zoetermeer, Holland). The volume signal was calibrated using a stroke volume and flow reference ratio derived from thermodilution cardiac output measurements obtained using the pulmonary artery catheter and a thermodilution computer (Wetenskappelijk Technische Instituut, Rotterdam, Holland). Parallel conductance for LV volume signal was measured using the hypertonic saline method (51). Left ventricular pressure and conductance data were recorded with a sampling rate of $250 \mathrm{~Hz}$ using a software package (PC Conduct, Cardiodynamics). All circulatory measurements were recorded and analyzed using a digital signal acquisition and analysis software package (Acqknowledge, Biopac Systems, Santa Barbara, CA).

Great cardiac vein flow $\left(\mathrm{Q}_{\mathrm{GCV}}\right)$ was measured by thermodilution. Coronary oxygen $\left(\mathrm{O}_{2}\right)$ kinetics were calculated as follows: arterial $\mathrm{O}_{2}$ content $=\left[\left(\right.\right.$ arterial partial pressure $\left.\mathrm{O}_{2} \times 0.23\right)+[$ hemoglobin concentration] $\left(1.39 \times\right.$ arterial $\mathrm{O}_{2}$ saturation)]; great cardiac vein $(\mathrm{GCV}) \mathrm{O}_{2}$ content $=\left\{\left(\mathrm{GCV}\right.\right.$ partial pressure $\left.\mathrm{O}_{2} \times 0.23\right)+$ [hemo-
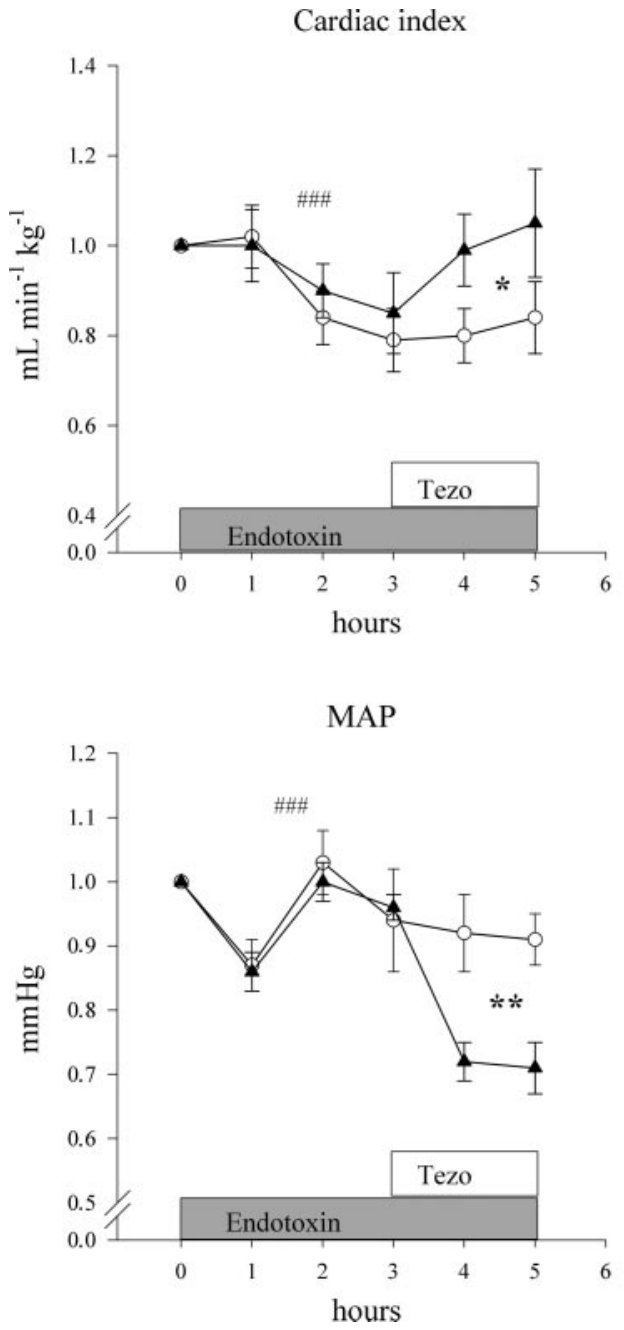
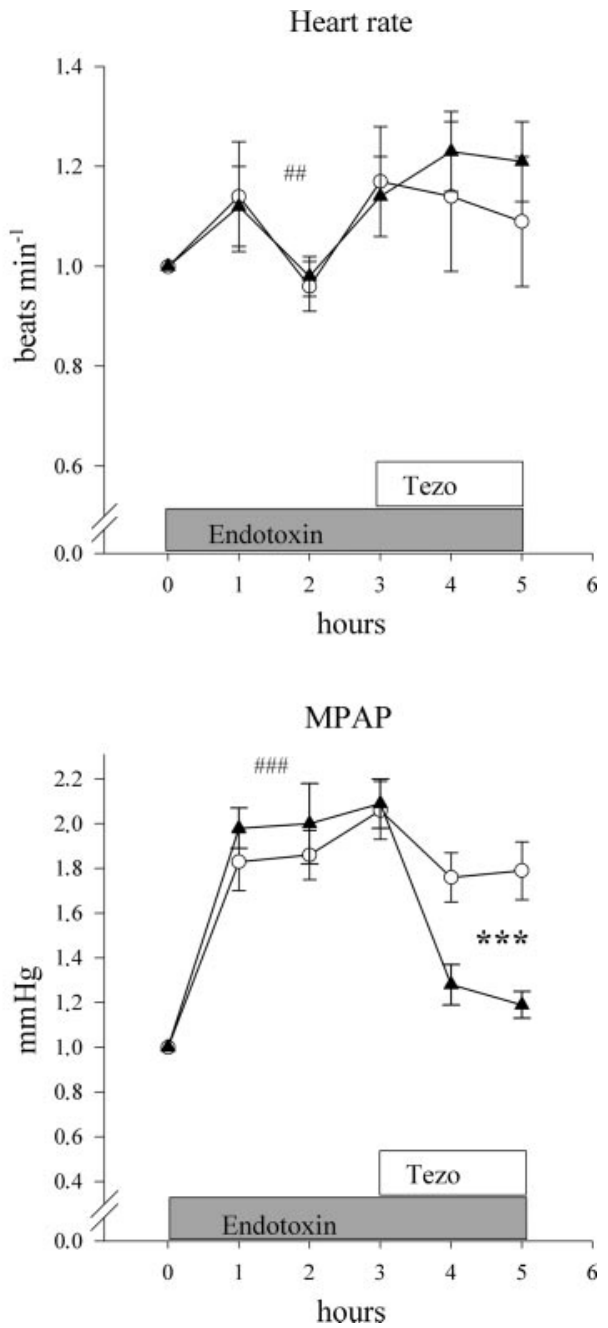

Fig. 1. Hemodynamic variables. General hemodynamics were studied following endotoxin administration $\left(0.25 \mu \mathrm{g} \cdot \mathrm{kg}^{-1} \cdot \mathrm{h}^{-1}\right)$ for $5 \mathrm{~h}$. After $3 \mathrm{~h}$ of endotoxemia, tezosentan administration (Tezo; $1 \mathrm{mg} \cdot \mathrm{kg}^{-1} \cdot \mathrm{h}^{-1}$ ) was started $(n=8, \mathbf{\Lambda})$ and compared with animals receiving endotoxin alone (controls, $n=8$, $\bigcirc$ ). Data are presented as means \pm SE, with relative changes from baseline. Effects of endotoxin before intervention are displayed as $\# \# P<0.01$, \#\#\#P $<0.001$. Significant differences between groups postintervention are displayed as $* * P<0.01$ and $* * * P<$ 0.001 . 
globin concentration] [1.39 $\times \mathrm{GCV} \mathrm{O}$ saturation $\left.\left(\mathrm{S}_{\mathrm{GCVO}_{2}}\right)\right]$; ; myocardial $\mathrm{O}_{2}$ delivery $\left(\mathrm{MDO}_{2}\right)=\mathrm{Q}_{\mathrm{GCV}} \times$ arterial $\mathrm{O}_{2}$ content; myocardial $\mathrm{O}_{2}$ consumption $\left(\mathrm{MVO}_{2}\right)=\left(\right.$ arterial $\mathrm{O}_{2}$ content $-\mathrm{GCV} \mathrm{O}_{2}$ content) $\times \mathrm{Q}_{\mathrm{GCV}}$; and myocardial $\mathrm{O}_{2}$ extraction ratio $(\mathrm{MOER})=$ $100 \times \mathrm{MVO}_{2} / \mathrm{DO}_{2}$. The units used for $\mathrm{O}_{2}$ content is milliliters per liter and for partial pressure in kilopascals.

General hemodynamic parameters for each point in the protocol were measured: heart rate (HR), mean arterial blood pressure (MAP), cardiac output, stroke volume (SV), central venous pressure (CVP), mean pulmonary artery pressure (MPAP), LV endsystolic volume, LV end-diastolic volume (LVEDV), LV endsystolic pressure, LV end-diastolic pressure, LV maximal rate of change in pressure $\left(\mathrm{dP} / \mathrm{d} t_{\max }\right)$, and maximum negative rate of pressure change $\left(\mathrm{dP} / \mathrm{d} t_{\min }\right)$. End diastole was identified as the maximum LV volume before isovolumic pressure increase, which was timed for the purpose of analysis of sequences with multiple heart cycles to 8-16 $\mathrm{ms}$ before measured $\mathrm{dP} / \mathrm{d} t_{\max }$ or $8-16 \mathrm{~ms}$ after the intracardiac ECG $\mathrm{R}$ wave. LV stroke work (SW) was measured from the integral of the pressure-volume area for each heart cycle. Power max (Power ${ }_{\max }$ ) was calculated for each beat as the maximal instantaneous pressureflow product during systole (41). The analysis of contractile parameters was made from a selection of contiguous beats within physiological pressure ranges and also based on strong linearity in the end-systolic pressure-volume $(\mathrm{P} / \mathrm{V})$ relation. The end-systolic points were initially estimated as maximal pressure/volume for each cycle, and these beats were used to establish an end-systolic pressurevolume relation (ESPVR) for all beats, with an $x$-intercept. A tangent to this $x$-intercept was then used to find a new end-systolic P/V point for all beats, and a final ESPVR (24). Total potential energy (PVA) was calculated for a single resting beat at the onset of a preload reduction sequence using the ESPVR and then $(0.5) \mathrm{P}_{\mathrm{es}}\left(\mathrm{V}_{\mathrm{es}}-\mathrm{V}_{\mathrm{o}}\right)$, where $P_{e s}$ was LV end-systolic pressure, $V_{\text {es }}$ was LV end-systolic volume, and $\mathrm{V}_{\mathrm{o}}$ was the $\mathrm{LV}$ volume at the $x$-intercept for the ESPVR. SW was calculated for the same beat, and myocardial efficiency was expressed as SW/PVA. For diastolic parameters, tau is the time constant for pressure decay during the isovolumic relaxation phase assuming a nonzero asymptote (9). Additionally, the half-time for pressure decay during isovolumic relaxation $\left(t_{1 / 2}\right)$ was measured (37).
Also, for each measurement point in the protocol, a controlled preload alteration was performed during a brief period of apnea using transient inflation of the balloon-tipped catheter to occlude the inferior vena cava for a short period $(6-8 \mathrm{~s})$. A sequence of $6-12$ contiguous heart cycles was later selected from this sequence for analysis, based on a progressive beat-to-beat reduction in end-diastolic and end-systolic LV volumes. This sequence was analyzed for endsystolic elastance $\left(\mathrm{E}_{\mathrm{es}}\right)(24)$ and preload recruitable stroke work (PRSW) (18). All myocardial function parameters were calculated using custom software.

Biochemical analyses. Plasma levels of ET-1-like immunoreactivity (ET-1 LI) were analyzed with radioimmunoassay, as described by Hemsén (22). Troponin I in plasma was analyzed by a two-position immunoenzymatic assay (Beckman Coulter, Fullerton, CA).

Experimental protocol. Upon completion of the preparation, a 45-min stabilization period was allowed. After baseline measurements, an intravenous infusion of endotoxin (Escherichia coli B0111: B4; Sigma, St. Louis, MO) was started in all animals beginning at $0.05 \mu \mathrm{g} \cdot \mathrm{kg}^{-1} \cdot \mathrm{h}^{-1}$ and gradually increased to reach 0.25 $\mu \mathrm{g} \cdot \mathrm{kg}^{-1} \cdot \mathrm{h}^{-1}$ within $45 \mathrm{~min}$. After $3 \mathrm{~h}$, eight animals received a short infusion of tezosentan ( $1 \mathrm{mg} / \mathrm{kg}$ in $10 \mathrm{~min})$ followed by a continuous infusion of tezosentan at $1 \mathrm{mg} \cdot \mathrm{kg}^{-1} \cdot \mathrm{h}^{-1}$. General hemodynamics, blood gases, and cardiac function were assessed every hour, and plasma samples for analyses of ET-1 LI and troponin I were drawn at baseline, after 3 and $5 \mathrm{~h}$.

Statistical analysis. Data are presented as means \pm SE. A univariate repeated-measures ANOVA was used for analyzing changes over time from baseline until $3 \mathrm{~h}$ for evaluating effects of endotoxin administration and for differences between groups before intervention. A repeated-measures ANOVA using the time point $3 \mathrm{~h}$ as a covariate was used for evaluating effects of tezosentan administration from 4 to $5 \mathrm{~h}$. Regarding ET-1 LI and troponin I, differences between groups postintervention were evaluated by ANOVA with analysis of the time-treatment interaction. Differences were considered significant at $P<0.05$. A computer software program (STATISTICA 7.0 StatSoft, Tulsa, OK) was utilized for statistical calculations.

Table 1. Hemodynamic and blood gas-derived parameters

\begin{tabular}{|c|c|c|c|c|c|c|c|c|}
\hline Parameter & Group & $0 \mathrm{~h}$ & $1 \mathrm{~h}$ & $2 \mathrm{~h}$ & $3 \mathrm{~h}$ & $4 \mathrm{~h}$ & $5 \mathrm{~h}$ & $P$ Values \\
\hline \multirow[t]{2}{*}{$\mathrm{SVI}, \mathrm{ml} \cdot \mathrm{kg}^{-1} \cdot$ beat $^{-1}$} & ctrl & $1.59 \pm 0.08$ & $1.42 \pm 0.12$ & $1.36 \pm 0.09$ & $1.15 \pm 0.11$ & $1.00 \pm 0.10$ & $1.05 \pm 0.10$ & \#\#\# \\
\hline & tezo & $1.88 \pm 0.16$ & $1.730 \pm 0.16$ & $1.67 \pm 0.21$ & $1.35 \pm 0.15$ & $1.45 \pm 0.12$ & $1.58 \pm 0.13$ & $*$ \\
\hline \multirow[t]{2}{*}{$\mathrm{CVP}, \mathrm{mmHg}$} & ctrl & $7.5 \pm 0.5$ & $9.3 \pm 0.4$ & $10.8 \pm 0.8$ & $9.3 \pm 0.4$ & $9.9 \pm 0.8$ & $10.1 \pm 0.8$ & \#\#\# \\
\hline & tezo & $7.2 \pm 0.5$ & $8.5 \pm 0.4$ & $10.1 \pm 0.4$ & $9.3 \pm 0.6$ & $7.5 \pm 0.2$ & $8.0 \pm 0.3$ & $*$ \\
\hline \multirow[t]{2}{*}{$\mathrm{SVRI}, \mathrm{mmHg} \cdot \mathrm{kg} \cdot \min \cdot \mathrm{ml}^{-1}$} & ctrl & $668 \pm 41$ & $592 \pm 48$ & $804 \pm 84$ & $786 \pm 86$ & $677 \pm 54$ & $665 \pm 47$ & \#\#\# \\
\hline & tezo & $697 \pm 51$ & $572 \pm 45$ & $757 \pm 61$ & $803 \pm 86$ & $511 \pm 52$ & $473 \pm 54$ & $* *$ \\
\hline \multirow[t]{2}{*}{$\mathrm{PVRI}, \mathrm{mmHg} \cdot \mathrm{kg} \cdot \mathrm{min} \cdot \mathrm{ml}^{-1}$} & ctrl & $49 \pm 9$ & $228 \pm 36$ & $233 \pm 14$ & $306 \pm 26$ & $276 \pm 29$ & $273 \pm 35$ & \\
\hline & tezo & $36 \pm 7$ & $189 \pm 18$ & $204 \pm 37$ & $266 \pm 35$ & $111 \pm 18$ & $79 \pm 11$ & $* * *$ \\
\hline \multirow[t]{2}{*}{$\mathrm{Sv}_{\mathrm{O}_{2}}, \%$} & ctrl & $69.3 \pm 3.1$ & $67.7 \pm 4.5$ & $60.3 \pm 4.8$ & $48.2 \pm 6.8$ & $48.9 \pm 6.3$ & $53.7 \pm 5.1$ & \#\#\# \\
\hline & tezo & $74.5 \pm 2.5$ & $72.9 \pm 3.4$ & $62.7 \pm 5.9$ & $58.3 \pm 6.1$ & $64.3 \pm 5.0$ & $65.8 \pm 4.2$ & $P=0.051$ \\
\hline \multirow[t]{2}{*}{ Hemoglobin, g/l } & ctrl & $85 \pm 3$ & $90 \pm 3$ & $98 \pm 4$ & $103 \pm 4$ & $101 \pm 3$ & $99 \pm 4$ & \#\#\# \\
\hline & tezo & $86 \pm 1$ & $92 \pm 2$ & $102 \pm 2$ & $107 \pm 2$ & $94 \pm 1$ & $90 \pm 1$ & $* * *$ \\
\hline \multirow[t]{2}{*}{$\mathrm{pH}$} & ctrl & $7.49 \pm 0.02$ & $7.47 \pm 0.01$ & $7.44 \pm 0.03$ & $7.41 \pm 0.03$ & $7.41 \pm 0.03$ & $7.42 \pm 0.03$ & \#\# \\
\hline & tezo & $7.50 \pm 0.02$ & $7.49 \pm 0.02$ & $7.45 \pm 0.04$ & $7.45 \pm 0.03$ & $7.49 \pm 0.02$ & $7.48 \pm 0.02$ & NS \\
\hline \multirow[t]{2}{*}{ Base excess, mM } & $\mathrm{ctrl}$ & $5.1 \pm 0.9$ & $3.3 \pm 0.7$ & $3.1 \pm 0.9$ & $2.1 \pm 0.9$ & $2.0 \pm 1.3$ & $2.1 \pm 1.3$ & \#\#\# \\
\hline & tezo & $4.9 \pm 0.9$ & $4.0 \pm 0.8$ & $3.7 \pm 1.0$ & $2.9 \pm 0.9$ & $5.3 \pm 0.9$ & $4.1 \pm 0.9$ & $P=0.069$ \\
\hline \multirow[t]{2}{*}{ Arterial $\mathrm{Po}_{2}, \mathrm{kPa}$} & ctrl & $25.3 \pm 1.4$ & $24.5 \pm 1.6$ & $22.7 \pm 2.5$ & $13.5 \pm 3.0$ & $13.7 \pm 3.1$ & $17.9 \pm 4.3$ & \#\#\# \\
\hline & tezo & $27.4 \pm 1.2$ & $24.5 \pm 1.8$ & $19.7 \pm 3.0$ & $16.8 \pm 3.5$ & $18.5 \pm 2.8$ & $18.1 \pm 2.5$ & NS \\
\hline \multirow[t]{2}{*}{ Arterial $\mathrm{PCO}_{2}, \mathrm{kPa}$} & ctrl & $5.0 \pm 0.2$ & $5.0 \pm 0.1$ & $5.0 \pm 0.3$ & $5.7 \pm 0.3$ & $5.7 \pm 0.3$ & $5.6 \pm 0.4$ & \# \\
\hline & tezo & $4.7 \pm 0.2$ & $4.8 \pm 0.2$ & $5.0 \pm 0.4$ & $5.2 \pm 0.3$ & $5.0 \pm 0.2$ & $5.0 \pm 0.2$ & NS \\
\hline
\end{tabular}

Data are presented as means $\pm \mathrm{SE}$. Hemodynamics and blood gases were studied following endotoxin administration $\left(0.25 \mathrm{mg} \cdot \mathrm{kg}^{-1} \cdot \mathrm{h}^{-1}\right)$ for $5 \mathrm{~h}$. After $3 \mathrm{~h}$

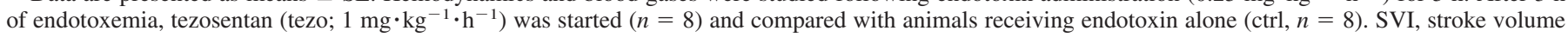

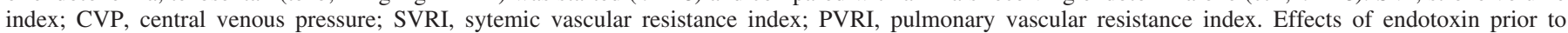

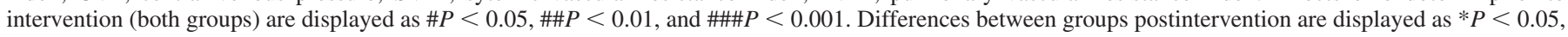
$* * P<0.01$, and $* * * P<0.001$. 


\section{RESULTS}

Effects on general circulation and metabolic parameters. Endotoxemia evoked a hypodynamic response with a prominent pulmonary hypertension seen as a decreases in cardiac index (CI), stroke volume, MAP and $\mathrm{Sv}_{\mathrm{O}_{2}}$, increases in $\mathrm{HR}$, systemic vascular resistance index (SVRI), CVP, as well as MPAP and PVRI. Gas exchange deteriorated and a metabolic acidosis was noted. Tezosentan improved CI and stroke volume, as well as reduced MAP, CVP and SVRI (Fig. 1 and Table 1). Pulmonary hypertension was abolished without further effects on gas exchange. A tendency to an increase in base excess and $\mathrm{Sv}_{\mathrm{O}_{2}}$ was also seen in response to tezosentan.

Effects on left ventricular systolic performance. The first $3 \mathrm{~h}$ of endotoxemia were not associated with detectable changes in parameters of systolic function. A trend $(P=0.052)$ for differences between groups prior to intervention were noticed regarding $\mathrm{E}_{\mathrm{es}}$. Tezosentan administration had negative effects on $\mathrm{E}_{\mathrm{es}}$, Power Pax $_{\max } / \mathrm{LVEV}$, and $\mathrm{dP} / \mathrm{d} t_{\text {max }} / \mathrm{LVEDV}$ (Fig. 2 and Table 2). A tendency toward decreased PRSW $(P=$ $0.067)$ and ejection fraction $(P=0.060)$ was also seen in response to tezosentan. SW/PVA was slightly reduced by endotoxin, and tezosentan had no effect on this parameter.

Effects on diastole/isovolumic relaxation. Endotoxin infusion had negative effects on the time constant for pressure decay, tau, whereas no significant effects regarding $t_{1 / 2}(P=$ 0.08 ) or LV stiffness were seen. Upon tezosentan administration, tau and $t_{1 / 2}$ were improved, and left ventricular stiffness decreased (Fig. 3).

Coronary blood flow and oxygen utilization. Neither $\mathrm{Q}_{\mathrm{GCV}}$ nor $\mathrm{S}_{\mathrm{GCV}} \mathrm{O}_{2}$ were affected by either endotoxin or tezosentan, whereas coronary perfusion pressure was modestly increased by endotoxin and likewise modestly decreased by tezosentan. $\mathrm{MDO}_{2}$ and $\mathrm{MV}_{2}$ were not affected by endotoxin, but there were significant differences between groups before intervention. $\mathrm{MDO}_{2}$ was slightly decreased in response to tezosentan. MOER was slightly increased in the tezosentan group compared with controls.

Biochemical parameters. Endotoxemia caused a twofold increase in plasma ET-1 LI immunoreactivity. Tezosentan further increased ET-1 LI and resulted in a fourfold increase compared with controls at $5 \mathrm{~h}$. Troponin levels were elevated in response to endotoxin by $57 \%$. Tezosentan did not influence this parameter (Fig. 4).

\section{DISCUSSION}

In this study we have demonstrated opposite inotropic and lusitropic cardiac effects of dual endothelin-receptor antagonism in endotoxemic pigs. First, tezosentan resulted in deterioration of left ventricular contractile performance. Second,
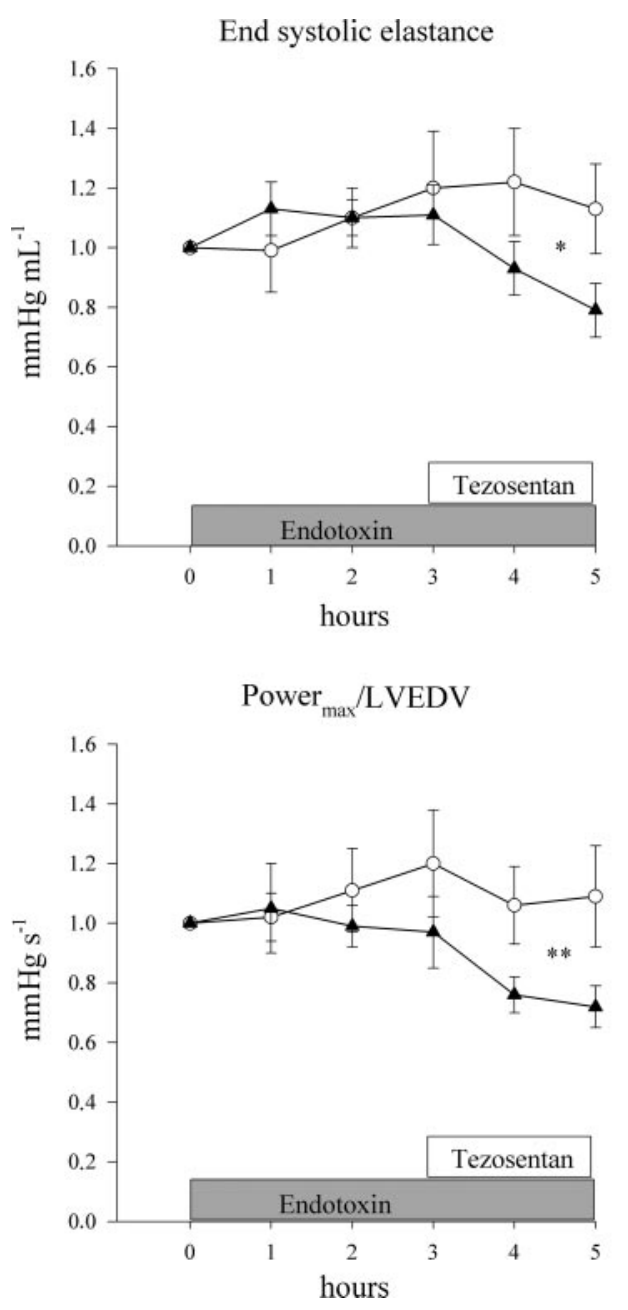
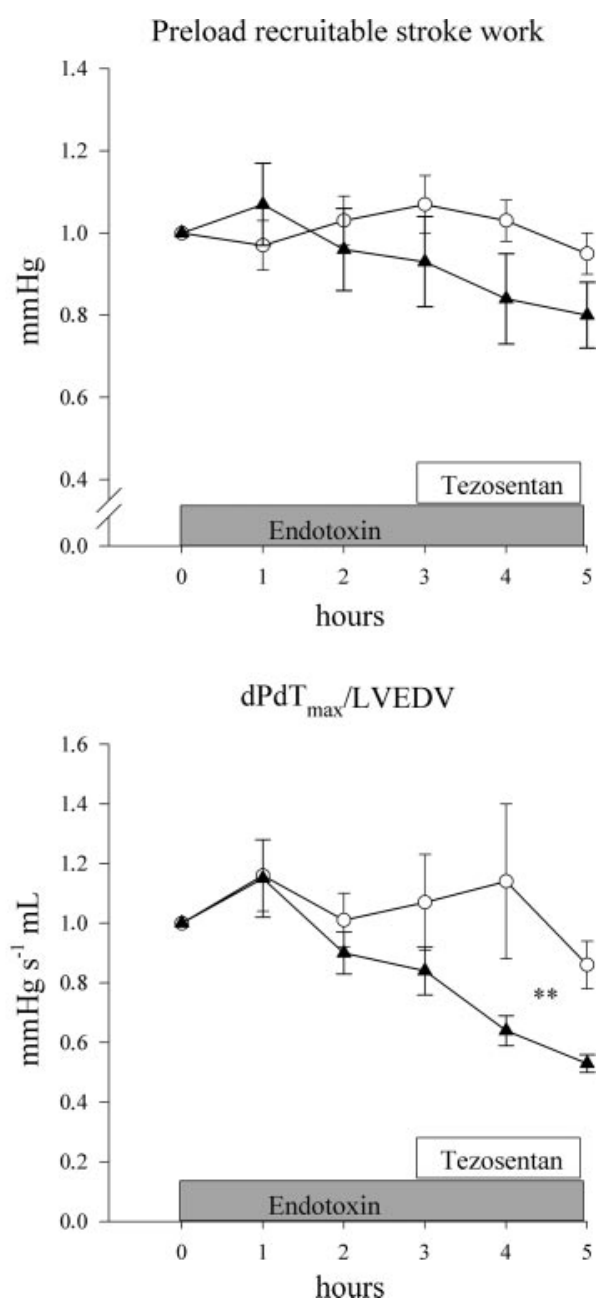

Fig. 2. Myocardial contractile function parameters: end-systolic elastance $\left(\mathrm{E}_{\mathrm{es}}\right)$, preload-recruitable stroke work (PRSW), power max $_{\text {ma }}$ end-diastolic volume (Power max $\left._{\text {a }} / \mathrm{EDV}\right)$ and $\mathrm{dP} /$ $\mathrm{d} t_{\max } / \mathrm{EDV}$ were studied following endotoxin administration $\left(0.25 \mu \mathrm{g} \cdot \mathrm{kg}^{-1} \cdot \mathrm{h}^{-1}\right)$ for $5 \mathrm{~h}$. After $3 \mathrm{~h}$ of endotoxemia, tezosentan (1 $\left.\mathrm{mg} \cdot \mathrm{kg}^{-1} \cdot \mathrm{h}^{-1}\right)$ was started $(n=8, \mathbf{\Lambda})$ and compared with animals receiving endotoxin alone (controls, $n=8, \circ$ ). Data are presented as means $\pm \mathrm{SE}$, with relative changes from baseline. Differences between groups postintervention are displayed as: $* P<0.05$ and $* * P<0.01$. 
Table 2. Cardiac effects

\begin{tabular}{|c|c|c|c|c|c|c|c|c|}
\hline Parameter & Group & $0 \mathrm{~h}$ & $1 \mathrm{~h}$ & $2 \mathrm{~h}$ & $3 \mathrm{~h}$ & $4 \mathrm{~h}$ & $5 \mathrm{~h}$ & $P$ Values \\
\hline \multirow[t]{2}{*}{$\mathrm{SW}, \mathrm{mmHg} / \mathrm{ml}$} & ctrl & $6105 \pm 791$ & $5061 \pm 789$ & $5338 \pm 665$ & $4231 \pm 491$ & $3640 \pm 491$ & $3657 \pm 337$ & \#\#\# \\
\hline & tezo & $6815 \pm 631$ & $5903 \pm 774$ & $6313 \pm 922$ & $5230 \pm 665$ & $4416 \pm 535$ & $4631 \pm 554$ & $*$ \\
\hline \multirow[t]{2}{*}{ LVEDP, mmHg } & ctrl & $14.4 \pm 1.5$ & $11.8 \pm 1.8$ & $12.8 \pm 1.3$ & $9.0 \pm 1.3$ & $10.7 \pm 1.4$ & $10.5 \pm 1.5$ & \#\#\# \\
\hline & tezo & $14.9 \pm 1.4$ & $12.5 \pm 1.1$ & $15.1 \pm 1.3$ & $11.3 \pm 1.3$ & $9.8 \pm 1.9$ & $11.9 \pm 1.3$ & $P=0.053$ \\
\hline \multirow{2}{*}{ LVEDV, ml } & ctrl & $114.5 \pm 9.8$ & $98.1 \pm 11.0$ & $99.7 \pm 7.6$ & $83.2 \pm 6.0$ & $74.9 \pm 9.0$ & $79.4 \pm 7.7$ & \# \\
\hline & tezo & $111.6 \pm 9.4$ & $98.7 \pm 8.9$ & $107.5 \pm 10.2$ & $101.3 \pm 8.4$ & $108.5 \pm 7.4$ & $122.0 \pm 6.8$ & $* *$ \\
\hline \multirow[t]{2}{*}{ LVESP, mmHg } & ctrl & $98.7 \pm 4.4$ & $84.7 \pm 3.0$ & $100.3 \pm 4.0$ & $90.1 \pm 5.0$ & $85.2 \pm 5.6$ & $85.8 \pm 3.6$ & \#\#\# \\
\hline & tezo & $105.9 \pm 2.7$ & $90.1 \pm 1.8$ & $106.0 \pm 5.5$ & $97.8 \pm 5.3$ & $75.8 \pm 3.7$ & $75.9 \pm 4.1$ & $* * *$ \\
\hline \multirow[t]{2}{*}{ LVESV, ml } & ctrl & $52.1 \pm 6.2$ & $40.0 \pm 4.8$ & $44.3 \pm 4.8$ & $36.2 \pm 6.1$ & $32.2 \pm 6.0$ & $35.3 \pm 5.3$ & \\
\hline & tezo & $42.7 \pm 4.6$ & $34.9 \pm 5.3$ & $43.5 \pm 5.0$ & $46.8 \pm 5.9$ & $53.3 \pm 5.9$ & $62.8 \pm 5.2$ & $* *$ \\
\hline \multirow{2}{*}{ SW/PVA } & ctrl & $0.60 \pm 0.03$ & $0.60 \pm 0.03$ & $0.59 \pm 0.04$ & $0.54 \pm 0.06$ & $0.60 \pm 0.03$ & $0.59 \pm 0.05$ & \# \\
\hline & tezo & $0.55 \pm 0.03$ & $0.60 \pm 0.04$ & $0.54 \pm 0.05$ & $0.51 \pm 0.04$ & $0.56 \pm 0.03$ & $0.54 \pm 0.02$ & $*$ \\
\hline \multirow[t]{2}{*}{$\mathrm{EF}, \%$} & ctrl & $58.3 \pm 2.4$ & $61.5 \pm 2.8$ & $58.2 \pm 3.8$ & $60.5 \pm 6.0$ & $61.4 \pm 4.3$ & $60.1 \pm 3.9$ & \\
\hline & tezo & $64.7 \pm 2.3$ & $69.1 \pm 5.8$ & $61.7 \pm 3.8$ & $57.8 \pm 4.9$ & $54.0 \pm 4.3$ & $51.8 \pm 3.7$ & $P=0.06$ \\
\hline \multirow[t]{2}{*}{$\mathrm{Q}_{\mathrm{GCV}}, \mathrm{ml} / \mathrm{min}$} & ctrl & $143 \pm 15$ & $132 \pm 16$ & $131 \pm 19$ & $134 \pm 12$ & $119 \pm 9$ & $128 \pm 17$ & \\
\hline & tezo & $115 \pm 24$ & $134 \pm 38$ & $170 \pm 51$ & $145 \pm 38$ & $108 \pm 26$ & $134 \pm 36$ & NS \\
\hline \multirow[t]{2}{*}{$\mathrm{S}_{\mathrm{GCV}} \mathrm{O}_{2}, \%$} & ctrl & $25.1 \pm 1.6$ & $26.5 \pm 2.4$ & $28.6 \pm 1.6$ & $23.4 \pm 2.5$ & $25.1 \pm 1.9$ & $29.6 \pm 2.8$ & \\
\hline & tezo & $23.2 \pm 1.0$ & $22.0 \pm 1.2$ & $24.2 \pm 1.9$ & $24.0 \pm 3.0$ & $24.3 \pm 2.0$ & $25.5 \pm 1.3$ & NS \\
\hline \multirow[t]{2}{*}{$\mathrm{MDO}_{2}, \mathrm{ml} / \mathrm{min}$} & ctrl & $17.6 \pm 2.1$ & $17.1 \pm 2.2$ & $17.4 \pm 2.5$ & $16.3 \pm 1.8$ & $15.2 \pm 1.8$ & $16.5 \pm 2.4$ & $\S$ \\
\hline & tezo & $14.2 \pm 2.9$ & $17.6 \pm 5.0$ & $24.6 \pm 7.6$ & $20.9 \pm 5.8$ & $14.2 \pm 3.4$ & $16.9 \pm 4.4$ & $*$ \\
\hline \multirow[t]{2}{*}{$\mathrm{MV}_{\mathrm{O}_{2}}, \mathrm{ml} / \mathrm{min}$} & ctrl & $12.2 \pm 1.9$ & $11.3 \pm 1.4$ & $10.8 \pm 1.2$ & $10.7 \pm 1.3$ & $9.7 \pm 1.3$ & $10.1 \pm 1.7$ & $\S$ \\
\hline & tezo & $11.0 \pm 2.2$ & $13.6 \pm 3.7$ & $18.0 \pm 5.2$ & $14.8 \pm 3.4$ & $10.5 \pm 2.3$ & $12.4 \pm 3.0$ & NS \\
\hline \multirow[t]{2}{*}{ MOER } & $\mathrm{ctrl}$ & $69.7 \pm 5.7$ & $68.4 \pm 5.1$ & $65.8 \pm 5.6$ & $67.4 \pm 5.8$ & $65.5 \pm 4.6$ & $63.0 \pm 5.4$ & \# \\
\hline & tezo & $77.7 \pm 1.1$ & $78.4 \pm 1.2$ & $75.4 \pm 1.5$ & $74.5 \pm 2.8$ & $75.7 \pm 1.7$ & $75.1 \pm 1.0$ & $*$ \\
\hline
\end{tabular}

Data are presented as means \pm SE. Cardiac effects were studied using LVPVR following endotoxin administration $\left(0.25 \mathrm{mg} \cdot \mathrm{kg}^{-1} \cdot \mathrm{h}^{-1}\right)$ for $5 \mathrm{~h}$. After $3 \mathrm{~h}$ of endotoxemia, tezo $\left(1 \mathrm{mg} \cdot \mathrm{kg}^{-1} \cdot \mathrm{h}^{-1}\right)$ was started $(n=8)$ and compared with animals receiving endotoxin alone $(\mathrm{ctrl}, n=8)$. SW, stroke work; LVEDP, left ventricular end-diastolic pressure; LVEDV, LV end-diastolic volume; LVESP, LV end-systolic pressure; PVA, total potential energy; EF, ejection fraction; $\mathrm{Q}_{\mathrm{GCV}}$, great cardiac vein flow; $\mathrm{S}_{\mathrm{GCVO}}, \mathrm{GCV} \mathrm{O}_{2}$ saturation; $\mathrm{MDO}_{2}$, myocardial $\mathrm{O}_{2}$ delivery; $\mathrm{MV}_{2}$, myocardial $\mathrm{O}_{2}$ consumption; $\mathrm{MOER}$, myocardial $\mathrm{O}_{2}$ extraction ratio. Effects of endotoxin prior to intervention are displayed as $\# P<0.05$ and \#\#\#P<0.001. Differences between groups prior to intervention are displayed as $\S P<0.05$. Differences between groups postintervention are displayed as $* P<0.05$ and $* * P<0.01$.

tezosentan significantly improved diastolic performance. These findings are somewhat surprising and in contrast to previously published findings where heart function was assessed with less sensitive methods (29).

Endotoxemia per se was not associated with detectable changes in myocardial contractile function in the present study. Similar in vivo findings have been described by others $(3,46)$, whereas some authors have reported increased $(12,23)$ or decreased $(1,32,62)$ contractile function in early endotoxemia. The abovementioned investigators have all used load-independent measures of contractility and endotoxin, although in different doses and serotypes and in various species. Therein lies possibly the explanation for the diverging reports. The manner by which endotoxin is infused is also important, where a continuous infusion of endotoxin is preferable to bolus infusions as a model of human sepsis because it generally produces a more persistent pathophysiological response (20). Our current results suggest that endotoxin did not cause detectable LV contractile impairment, but sympathetic activation in response to endotoxin may very well have compensated for a negative inotropic effect of endotoxin, as suggested by Smith et al. $(12,50)$. The increase in HR seen following endotoxemia would support this concept but when blocking baroreceptor reflexes, Aghajani et al. (2) still could not see evidence of impaired contractility in endotoxemic pigs. Intriguingly, Ishihara et al. (23) reported biphasic, time-dependent changes in LV systolic performance in awake pigs receiving continuous infusion of endotoxin for $24 \mathrm{~h}$. They reported an initial increase in $E_{e s}$ in the first hours followed by a significant sustained decrease in $\mathrm{E}_{\mathrm{es}}$ after $7 \mathrm{~h}$ and onward. Studies in humans of myocardial depression are invariably not done within the first few hours of sepsis debut, but investigators often find depressed systolic function upon presentation in the intensive care unit and days thereafter (48). Our findings, within the limited time frame under which they are conducted, do not rule out the possibility that ET-1 may play a significant role in the clinical presentation of depressed systolic function at a later stage of sepsis as well. Interestingly, ET plasma levels have been shown to remain elevated in up to 28 days after onset of severe sepsis (55).

Although many studies performed in vitro in various species show conflicting results regarding myocardial effects of ET-1 $(49,65)$, there are several reports done in larger animals and humans that seem to indicate positive inotropic effects of ET-1 under nondisease conditions $(33,60)$. We recently reported that exogenous ET-1 administered into the coronary circulation had positive, dose-related effects on LV systolic performance in a nonseptic setting (30).

Interestingly, in pathological states, such as congestive heart failure, ET receptor antagonism has shown positive effects in some clinical trials (54) but with increasing doses, the overall effect may be negative. Similarly, there are reports on ET-1 exerting negative inotropic effects during pathological conditions such as congestive heart failure $(33,53)$.

Despite an improved CI, tezosentan administration was associated with impairment of LV contractile status. In our previous studies, we have shown beneficial effects on CI, SV, SW, and survival using dual ET receptor antagonists $(29,58)$. However, load-independent measures of LV contractile performance were not used in those studies. The positive effects seen may well have been due to reductions in afterload. In the present study, we therefore utilized LVPVR to minimize load- 
Tau
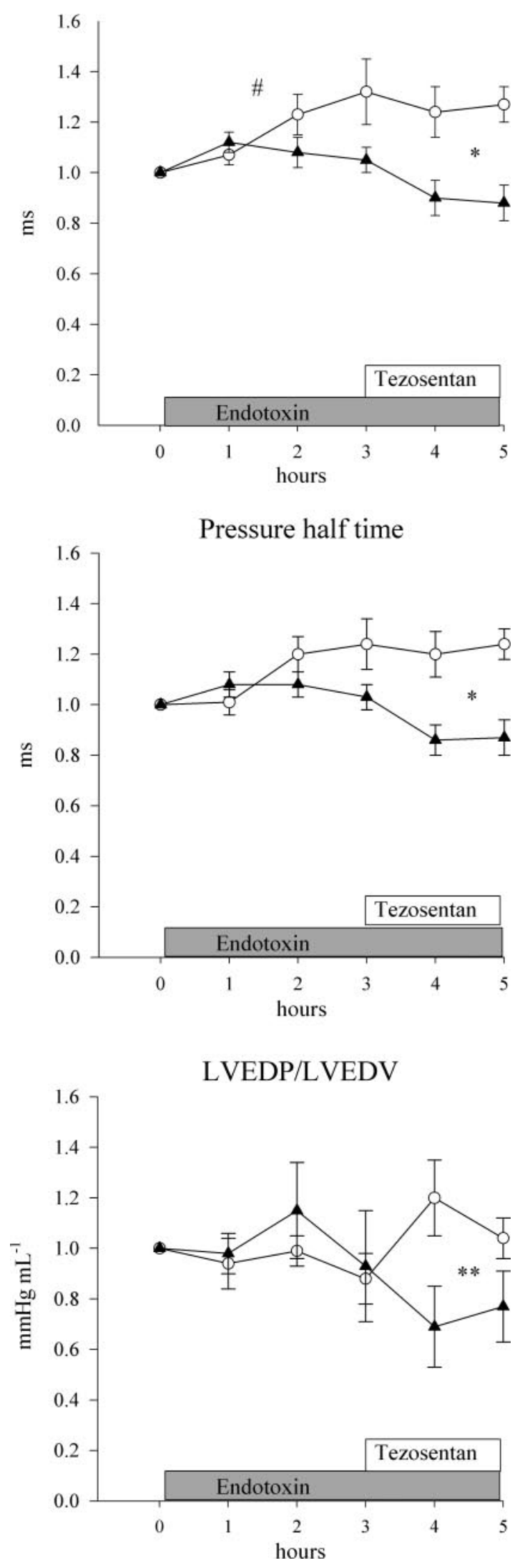

ing confounders, a method previously validated by others (52). Sepsis and endotoxemia are associated with marked alterations in both pre- and afterload, making the choice of method crucial for analyzing myocardial effects in vivo.

In the current paper Ees, $\mathrm{PWR}_{\max } / \mathrm{LVEDV}$, and $\mathrm{dP} / \mathrm{d} t_{\max } /$ LVEDV all decreased in response to tezosentan, and there was a tendency for PRSW to move in the same direction. Because all of these load-independent parameters show congruent results, the conclusion that tezosentan had negative inotropic effects in this setting is fair. This is also in agreement with our recent study in which intracoronary ET-1 administration was associated with increased myocardial contractile function in "nonseptic" pigs (30), an effect likely mediated by $\mathrm{ET}_{\mathrm{A}}$ receptors. The inotropic effect of $\mathrm{ET}_{\mathrm{A}}$-receptor activation has previously been described $(25,33)$, and this activation is thought to lead to increased sensitivity of the myofilaments for $\mathrm{Ca}^{2+}$ via the $\mathrm{Na}^{+} / \mathrm{H}^{+}$exchanger, thus increasing cytoplasmic $\mathrm{pH}$, increase in the inward $\mathrm{Ca}^{2+}$ current during depolarization and posttranslational modification of myofibrillar proteins (63). Few investigators have proposed the $\mathrm{ET}_{\mathrm{B}}$ receptor as primarily responsible for the inotropic effects of ET-1 (5). Our current data implicate that the increase in ET-1 levels seen in endotoxemia may provide a response to uphold $\mathrm{LV}$ contractile function.

The effects of endotoxemia on general hemodynamics were primarily hypodynamic, and pulmonary hypertension was prominent. Gas exchange was impaired, seen as decrease in $\mathrm{Pa}_{2}$ and increase in $\mathrm{PaCO}_{2}$. Tezosentan administration was associated with increases in CI and stroke volume index, as well as decreases in SVRI, MPAP, PVRI, and CVP, whereas MAP was further decreased and HR was unaffected. The beneficial findings on global hemodynamics are possibly related to the vasodilatory effects of dual ET-receptor antagonism, more pronounced in a state of sepsis in which the ET system is markedly activated (fourfold increase in plasma ET-1 LI levels) than in a state of nonseptic anesthetized pigs (35).

Mechanical efficiency (SW/PVA) was also studied, and there was a modest decrease in response to endotoxin before intervention. In another pig model of endotoxemia, mechanical efficiency was also impaired (3), and similar findings have been shown in septic models in rats (26) and dogs (28). Contrarily, Constable et al. (12) demonstrated increased SW/ PVA in endotoxemic neonatal calves. SW/PVA is most reliable as a measure of in vivo mechanical efficiency if ventricular load and heart rate are maintained relatively constant during serial mechanical efficiency measures. These were not experimentally controlled in this model.

In the literature, there is some evidence that ET-1 improves contractile efficiency in vitro (63, and references therein). This means that antagonizing the ET system would impair myocardial efficiency but, in the current study, tezosentan administration was not associated with further effects on SW/PVA.

Fig. 3. Diastolic parameters. Isovolumic relaxation parameters, tau and pressure half-time, as well as left ventricular stiffness were studied following endotoxin administration $\left(0.25 \mu \mathrm{g} \cdot \mathrm{kg}^{-1} \cdot \mathrm{h}^{-1}\right)$ for $5 \mathrm{~h}$. After $3 \mathrm{~h}$ of endotoxemia, tezosentan $\left(1 \mathrm{mg} \cdot \mathrm{kg}^{-1} \cdot \mathrm{h}^{-1}\right)$ was started $(n=8, \mathbf{\Lambda})$ and compared with animals receiving endotoxin alone (controls, $n=8, \circ$ ). Data are presented as means $\pm \mathrm{SE}$, with relative changes from baseline. Effects of endotoxin before intervention are displayed as $\# P<0.05$. Differences between groups postintervention are displayed as $* P<0.05$ and $* * P<0.01$. 
A

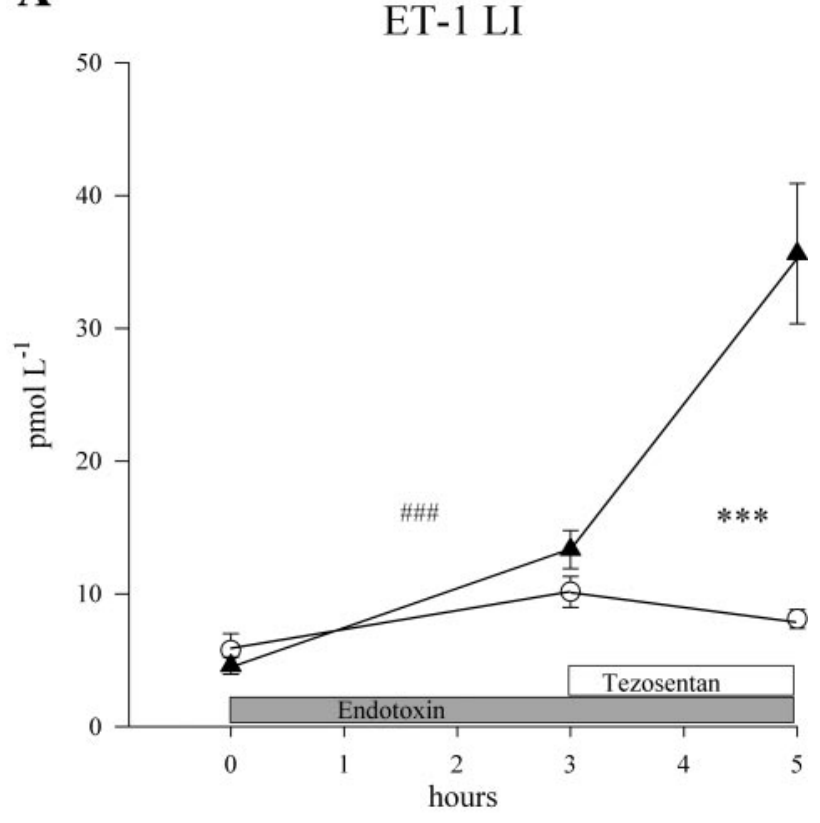

B

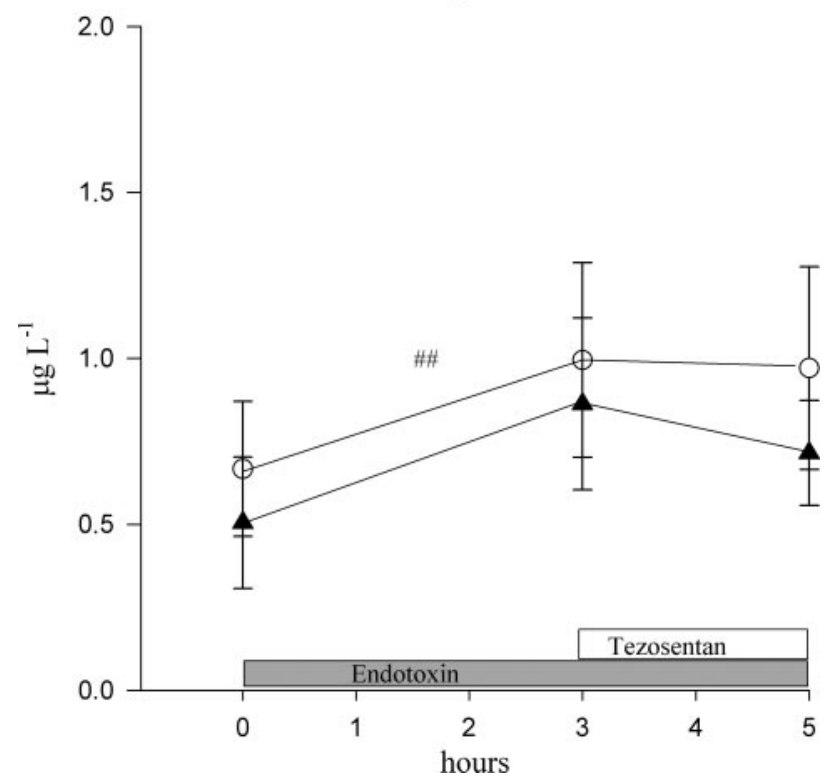

Fig. 4. Endothelin-1-like immunoreactivity (ET-1 LI; $A$ ) and troponin I $(B)$ in arterial plasma were studied following endotoxin administration $(0.25$ $\left.\mu \mathrm{g} \cdot \mathrm{kg}^{-1} \cdot \mathrm{h}^{-1}\right)$ for $5 \mathrm{~h}$. After $3 \mathrm{~h}$ of endotoxemia, tezosentan $\left(1 \mathrm{mg} \cdot \mathrm{kg}^{-1} \cdot \mathrm{h}^{-1}\right)$ was started $(n=8, \mathbf{\Delta})$ and was compared with animals receiving endotoxin alone (controls, $n=8, \circ$ ). Data are presented as means \pm SE. Effects of endotoxin are displayed as \#\#P $<0.01$ and \#\#\#P<0.001. Differences between groups postintervention are displayed as $* * * P<0.001$.

Endotoxemia was associated with deterioration of isovolumic relaxation, seen as prolongation of tau, but had no evident effects on LV stiffness. Several investigators have reported similar findings $(1,62)$. In healthy volunteers, Kiely et al. (27) infused ET-1 intravenously and found impaired LV relaxation using echocardiographic parameters. In a cecal inoculation model in rats, Brahmbhatt and coworkers (6) could show prolongation of tau at 12 and $24 \mathrm{~h}$ postinoculation, which was further prolonged by infusing BigET-1, a precursor of ET-1. This suggests that sepsis per se as well as the ET system impairs LV isovolumic relaxation. Diastolic dysfunction is also seen in septic patients either as a sole manifestation of septic myocardial depression or in conjunction with systolic dysfunction (48).

Tezosentan improved isovolumic relaxation (tau and $\mathrm{t}^{1 / 2}$ ) and decreased LV stiffness. These findings are in line with our previous work (29) in which high-volume resuscitated endotoxemic pigs improved measures of LV stiffness when treated with tezosentan in the same dosage. In a recent study from our group, we administered either ET-1 or sarafotoxin $6 \mathrm{c}$, a selective $\mathrm{ET}_{\mathrm{B}}$-receptor agonist, into the coronary circulation (30). Both of these peptides were associated with deteriorated isovolumic relaxation (tau and $t_{1 / 2}$ ) which suggest that the $\mathrm{ET}_{\mathrm{B}-}$ receptor is strongly involved. ET receptor antagonism has also been beneficial in this regard in other models. Goldberg et al. (19) reported impairment in human myocyte relaxation upon ET-1 administration, which was attenuated by an ET $_{\mathrm{A}}$-receptor antagonist, and Mebazaa et al. (34) reported that papillary muscles from rabbits exposed to endotoxin in vivo could show prolonged time to half relaxation, which was counteracted by an $\mathrm{ET}_{\mathrm{A}}$-receptor antagonist. These authors found the $\mathrm{ET}_{\mathrm{A}^{-}}$ receptor responsible for the negative lusitropic effects, whereas our previous results strongly suggest the ET $_{\mathrm{B}}$-receptor (30). The present data do not discriminate which of the ET receptors are responsible for the effects seen. However, while being a dual ET receptor antagonist, tezosentan has a high $\mathrm{ET}_{\mathrm{A}} / \mathrm{ET}_{\mathrm{B}}$ antagonizing effect ratio (11). Therefore, a high degree of $\mathrm{ET}_{\mathrm{A}}$-receptor antagonism would be expected in this model, suggesting that the results possibly were mainly due to $\mathrm{ET}_{\mathrm{A}^{-}}$ receptor antagonism. On the other hand, there is clear evidence of $\mathrm{ET}_{\mathrm{B}}$-receptor antagonizing effects by tezosentan seen as increased levels of plasma ET-1 LI. The elevation of plasma ET-1 upon ET receptor antagonism depends upon blocking pulmonary endothelial $\mathrm{ET}_{\mathrm{B}}$-receptors, which are responsible for the clearing function of circulating ET-1 (16).

These results suggest that specific $\mathrm{ET}_{\mathrm{B}}$ receptor antagonism could be preferable, improving diastolic function without negatively affecting systole. However, in a previous study from our group, selective $\mathrm{ET}_{\mathrm{B}}$-receptor antagonism proved detrimental during endotoxemia, probably due to unopposed vasoconstriction mediated by $\mathrm{ET}_{\mathrm{A}}$ receptors and decreased ET clearance (57).

Endotoxemia was not associated with any effects on cardiac oxygen utilization parameters or $\mathrm{Q}_{\mathrm{GCV}}$. MOER decreased somewhat in response to endotoxin, an effect also seen in human sepsis (14). As previously reported in both human sepsis and animal endotoxemia (29) cardiac troponin I was increased in response to endotoxin. The mechanisms behind this phenomenon are yet unclear, but mere ischemia is unlikely since neither in this model nor in human sepsis is myocardial hypoperfusion evident (14). Tezosentan administration was coupled to a modest decrease in $\mathrm{MDO}_{2}$, possibly related to the concomitant decrease in hemoglobin, and a modest increase in MOER. These effects were quite small and are less likely to have had an impact on the results of cardiac function. Interestingly, a recent report from Merkus et al. (36) suggests a local regulating factor responsible for abolished ET-1-medi- 
ated constrictor effect on coronary resistance vessels. Cardiac troponin I was not affected by tezosentan.

In conclusion, in this porcine model of early endotoxemia dual ET receptor antagonism with tezosentan was associated with a reduction in contractile function, despite improved global hemodynamic parameters. In contrast, ET receptor antagonism seemed to improve diastolic function. Positive hemodynamic effects from ET receptor antagonism in acute endotoxemia may be due to changes in cardiac load and enhanced diastolic function rather than improved contractile function.

\section{ACKNOWLEDGMENTS}

The authors thank Sören Häggmark and Pernilla Abrahamsson for excellent technical assistance and to Margareta Stensdotter for analyzing ET-1.

\section{GRANTS}

This study was supported by grants from the Swedish Heart Lung Foundation, the Swedish Research Council, the Swedish Medical Society, and Actelion Pharmaceuticals, as well as funds from the Karolinska Institute.

\section{REFERENCES}

1. Abel FL, Krosl P, Redl H. Beat-to-beat evaluation of cardiac function in low-dose endotoxemia using a conscious sheep model. Shock 16: $368-$ 372, 2001.

2. Aghajani E, Korvald C, Nordhaug D, Revhaug A, Myrmel T. Increased oxygen cost of contractility in the endotoxemic porcine left ventricle. Scand Cardiovasc J 38: 187-192, 2004

3. Aghajani E, Korvald C, Nordhaug D, Sager G, Revhaug A, Myrmel TE. Coli sepsis induces profound mechanoenergetic inefficiency in the porcine left ventricle. Shock 21: 103-109, 2004.

4. Awane-Igata Y, Ikeda S, Watanabe T. Inhibitory effects of TAK-044 on endothelin induced vasoconstriction in various canine arteries and porcine coronary arteries: a comparison with selective ETA and ETB receptor antagonists. Br J Pharmacol 120: 516-522, 1997.

5. Beyer ME, Slesak G, Brehm BR, Hoffmeister HM. Hemodynamic and inotropic effects of the endothelin A antagonist BQ-610 in vivo. J Cardiovasc Pharmacol 31, Suppl 1: S258-S261, 1998.

6. Brahmbhatt S, Gupta A, Sharma AC. Bigendothelin-1 (1-21) fragment during early sepsis modulates tau, p38-MAPK phosphorylation and nitric oxide synthase activation. Mol Cell Biochem 271: 225-237, 2005.

7. Brauner JS, Rohde LE, Clausell N. Circulating endothelin-1 and tumor necrosis factor-alpha: early predictors of mortality in patients with septic shock. Intensive Care Med 26: 305-313, 2000.

8. Broome M, Haney M, Osterlund B, Haggmark S, Johansson G, Biber B. The cardiac effects of intracoronary angiotensin II infusion. Anesth Analg 94: 787-793, 2002.

9. Brutsaert DL, Sys SU. Relaxation and diastole of the heart. Physiol Rev 69: 1228-1315, 1989.

10. Chin A, Radhakrishnan J, Fornell L, John E. Effects of tezosentan, a dual endothelin receptor antagonist, on the cardiovascular and renal systems of neonatal piglets during endotoxic shock. J Pediatr Surg 37: 482-487, 2002.

11. Clozel M, Ramuz H, Clozel JP, Breu V, Hess P, Loffler BM, Coassolo P, Roux S. Pharmacology of tezosentan, new endothelin receptor antagonist designed for parenteral use. J Pharmacol Exp Ther 290: 840-846, 1999.

12. Constable PD. Acute endotoxemia increases left ventricular contractility and diastolic stiffness in calves. Shock 12: 391-401, 1999.

13. Court O, Kumar A, Parrillo JE. Clinical review: Myocardial depression in sepsis and septic shock. Crit Care 6: 500-508, 2002.

14. Cunnion RE, Schaer GL, Parker MM, Natanson C, Parrillo JE. The coronary circulation in human septic shock. Circulation 73: 637-644, 1986.

15. de Nucci G, Thomas R, D'Orleans-Juste P, Antunes E, Walder C, Warner TD, Vane JR. Pressor effects of circulating endothelin are limited by its removal in the pulmonary circulation and by the release of prostacyclin and endothelium-derived relaxing factor. Proc Natl Acad Sci USA 85: 9797-9800, 1988.
16. Dupuis J, Goresky CA, Fournier A. Pulmonary clearance of circulating endothelin-1 in dogs in vivo: exclusive role of ETB receptors. $J$ Appl Physiol 81: 1510-1515, 1996.

17. Filep JG, Foldes-Filep E, Rousseau A, Sirois P, Fournier A. Vascular responses to endothelin-1 following inhibition of nitric oxide synthesis in the conscious rat. Br J Pharmacol 110: 1213-1221, 1993.

18. Glower DD, Spratt JA, Snow ND, Kabas JS, Davis JW, Olsen CO, Tyson GS, Sabiston DC Jr, Rankin JS. Linearity of the Frank-Starling relationship in the intact heart: the concept of preload recruitable stroke work. Circulation 71: 994-1009, 1985.

19. Goldberg AT, Bond BR, Mukherjee R, New RB, Zellner JL, Crawford FA Jr, Spinale FG. Endothelin receptor pathway in human left ventricular myocytes: relation to contractility. Ann Thorac Surg 69: 711-715; discussion 716, 2000.

20. Gupta A, Brahmbhatt S, Kapoor R, Loken L, Sharma AC. Chronic peritoneal sepsis: myocardial dysfunction, endothelin and signaling mechanisms. Front Biosci 10: 3183-3205, 2005.

21. Haney MF, Johansson G, Haggmark S, Biber B. Method of preload reduction during LVPVR analysis of systolic function: airway pressure elevation and vena cava occlusion. Anesthesiology 97: 436-446, 2002.

22. Hemsen A. Biochemical and functional characterization of endothelin peptides with special reference to vascular effects. Acta Physiol Scand Suppl 602: 1-61, 1991.

23. Ishihara S, Ward JA, Tasaki O, Pruitt BA Jr, Javors MA, Cassidy RA, Mozingo DW. Biphasic changes in left ventricular function during hyperdynamic endotoxemia. Am J Physiol Regul Integr Comp Physiol 276: R1516-R1524, 1999.

24. Kass DA, Maughan WL, Guo ZM, Kono A, Sunagawa K, Sagawa K. Comparative influence of load versus inotropic states on indexes of ventricular contractility: experimental and theoretical analysis based on pressure-volume relationships. Circulation 76: 1422-1436, 1987.

25. Kelso EJ, McDermott BJ, Silke B, Spiers JP. Endothelin(A) receptor subtype mediates endothelin-induced contractility in left ventricular cardiomyocytes isolated from rabbit myocardium. J Pharmacol Exp Ther 294: 1047-1052, 2000.

26. Khadour FH, Panas D, Ferdinandy P, Schulze C, Csont T, Lalu MM, Wildhirt SM, Schulz R. Enhanced NO and superoxide generation in dysfunctional hearts from endotoxemic rats. Am J Physiol Heart Circ Physiol 283: H1108-H1115, 2002.

27. Kiely DG, Cargill RI, Struthers AD, Lipworth BJ. Cardiopulmonary effects of endothelin-1 in man. Cardiovasc Res 33: 378-386, 1997.

28. Kline JA, Gordon BE, Williams C, Blumenthal S, Watts JA, DiazBuxo J. Large-pore hemodialysis in acute endotoxin shock. Crit Care Med 27: 588-596, 1999.

29. Konrad D, Oldner A, Rossi P, Wanecek M, Rudehill A, Weitzberg E. Differentiated and dose-related cardiovascular effects of a dual endothelin receptor antagonist in endotoxin shock. Crit Care Med 32: 1192-1199, 2004.

30. Konrad D, Oldner A, Wanecek M, Rudehill A, Weitzberg E, Biber B, Johansson G, Haggmark S, Haney M. Positive inotropic and negative lusitropic effects of endothelin receptor agonism in vivo. Am J Physiol Heart Circ Physiol 289: H1702-H1709, 2005.

31. Kumar A, Krieger A, Symeoneides S, Parrillo JE. Myocardial dysfunction in septic shock: Part II. Role of cytokines and nitric oxide. J Cardiothorac Vasc Anesth 15: 485-511, 2001.

32. Lee K, van der Zee H, Dziuban SW Jr, Luhmann K, Goldfarb RD. Left ventricular function during chronic endotoxemia in swine. Am J Physiol Heart Circ Physiol 254: H324-H330, 1988.

33. MacCarthy PA, Grocott-Mason R, Prendergast BD, Shah AM. Contrasting inotropic effects of endogenous endothelin in the normal and failing human heart: studies with an intracoronary ET(A) receptor antagonist. Circulation 101: 142-147, 2000.

34. Mebazaa A, De Keulenaer GW, Paqueron X, Andries LJ, Ratajczak P, Lanone S, Frelin C, Longrois D, Payen D, Brutsaert DL, Sys SU. Activation of cardiac endothelium as a compensatory component in endotoxin-induced cardiomyopathy: role of endothelin, prostaglandins, and nitric oxide. Circulation 104: 3137-3144, 2001.

35. Merkus D, Houweling B, Mirza A, Boomsma F, van den Meiracker AH, Duncker DJ. Contribution of endothelin and its receptors to the regulation of vascular tone during exercise is different in the systemic, coronary and pulmonary circulation. Cardiovasc Res 59: 745-754, 2003.

36. Merkus D, Houweling B, van den Meiracker AH, Boomsma F, Duncker DJ. Contribution of endothelin to coronary vasomotor tone is 
abolished after myocardial infarction. Am J Physiol Heart Circ Physiol 288: H871-H880, 2005.

37. Mirsky I. Assessment of diastolic function: suggested methods and future considerations. Circulation 69: 836-841, 1984.

38. Modesti PA, Vanni S, Paniccia R, Perna A, Maccherini M, Lisi G, Sani G, Neri Serneri GG. Endothelin receptors in adult human and swine isolated ventricular cardiomyocytes. Biochem Pharmacol 58: 369-374, 1999.

39. Molenaar P, O'Reilly G, Sharkey A, Kuc RE, Harding DP, Plumpton C, Gresham GA, Davenport AP. Characterization and localization of endothelin receptor subtypes in the human atrioventricular conducting system and myocardium. Circ Res 72: 526-538, 1993.

40. Munt B, Jue J, Gin K, Fenwick J, Tweeddale M. Diastolic filling in human severe sepsis: an echocardiographic study. Crit Care Med 26: 1829-1833, 1998.

41. Nakayama M, Chen CH, Nevo E, Fetics B, Wong E, Kass DA. Optimal preload adjustment of maximal ventricular power index varies with cardiac chamber size. Am Heart J 136: 281-288, 1998.

42. Ognibene FP, Parker MM, Natanson C, Shelhamer JH, Parrillo JE. Depressed left ventricular performance. Response to volume infusion in patients with sepsis and septic shock. Chest 93: 903-910, 1988.

43. Oldner A, Wanecek M, Weitzberg E, Sundin P, Sollevi A, Rubio C, Hellstrom PM, Alving K, Rudehill A. Differentiated effects on splanchnic homeostasis by selective and non-selective endothelin receptor antagonism in porcine endotoxaemia. Br J Pharmacol 127: 1793-1804, 1999.

44. Parker MM, McCarthy KE, Ognibene FP, Parrillo JE. Right ventricular dysfunction and dilatation, similar to left ventricular changes, characterize the cardiac depression of septic shock in humans. Chest 97: 126-131, 1990.

45. Parker MM, Shelhamer JH, Bacharach SL, Green MV, Natanson C, Frederick TM, Damske BA, Parrillo JE. Profound but reversible myocardial depression in patients with septic shock. Ann Intern Med 100: 483-490, 1984.

46. Pinsky MR, Rico P. Cardiac contractility is not depressed in early canine endotoxic shock. Am J Respir Crit Care Med 161: 1087-1093, 2000.

47. Plumpton C, Ashby MJ, Kuc RE, O'Reilly G, Davenport AP. Expression of endothelin peptides and mRNA in the human heart. Clin Sci (Lond) 90: 37-46, 1996.

48. Poelaert J, Declerck C, Vogelaers D, Colardyn F, Visser CA. Left ventricular systolic and diastolic function in septic shock. Intensive Care Med 23: 553-560, 1997.

49. Sakurai K, Norota I, Tanaka H, Kubota I, Tomoike H, Endo M. Negative inotropic effects of angiotensin II, endothelin-1 and phenylephrine in indo-1 loaded adult mouse ventricular myocytes. Life Sci 70: 1173-1184, 2002.

50. Smith LW, McDonough KH. Inotropic sensitivity to beta-adrenergic stimulation in early sepsis. Am J Physiol Heart Circ Physiol 255: H699_ H703, 1988.

51. Steendijk P, Staal E, Jukema JW, Baan J. Hypertonic saline method accurately determines parallel conductance for dual-field conductance catheter. Am J Physiol Heart Circ Physiol 281: H755-H763, 2001.
52. Steendijk P, Van der Velde ET, Baan J. Left ventricular stroke volume by single and dual excitation of conductance catheter in dogs. Am J Physiol Heart Circ Physiol 264: H2198-H2207, 1993.

53. Thomas PB, Liu EC, Webb ML, Mukherjee R, Hebbar L, Spinale FG. Exogenous effects and endogenous production of endothelin in cardiac myocytes: potential significance in heart failure. Am J Physiol Heart Circ Physiol 271: H2629-H2637, 1996.

54. Torre-Amione G, Young JB, Durand J, Bozkurt B, Mann DL, Kobrin I, Pratt CM. Hemodynamic effects of tezosentan, an intravenous dual endothelin receptor antagonist, in patients with class III to IV congestive heart failure. Circulation 103: 973-980, 2001.

55. Tschaikowsky K, Sagner S, Lehnert N, Kaul M, Ritter J. Endothelin in septic patients: effects on cardiovascular and renal function and its relationship to proinflammatory cytokines. Crit Care Med 28: 1854-1860, 2000.

56. Wanecek M, Oldner A, Rudehill A, Sollevi A, Alving K, Weitzberg E. Cardiopulmonary dysfunction during porcine endotoxin shock is effectively counteracted by the endothelin receptor antagonist bosentan. Shock 7: 364-370, 1997.

57. Wanecek M, Oldner A, Sundin P, Alving K, Weitzberg E, Rudehill A. Effects on haemodynamics by selective endothelin ET(B) receptor and combined endothelin ET(A)/ET(B) receptor antagonism during endotoxin shock. Eur J Pharmacol 386: 235-245, 1999.

58. Wanecek M, Weitzberg E, Alving K, Rudehill A, Oldner A. Effects of the endothelin receptor antagonist bosentan on cardiac performance during porcine endotoxin shock. Acta Anaesthesiol Scand 45: 1262-1270, 2001.

59. Wanecek M, Weitzberg E, Rudehill A, Oldner A. The endothelin system in septic and endotoxin shock. Eur J Pharmacol 407: 1-15, 2000.

60. Watanabe T, Kusumoto K, Kitayoshi T, Shimamoto N. Positive inotropic and vasoconstrictive effects of endothelin-1 in in vivo and in vitro experiments: characteristics and the role of L-type calcium channels. J Cardiovasc Pharmacol 13 Suppl 5: S108-S111; discussion S123, 1989.

61. Weitzberg E, Lundberg JM, Rudehill A. Elevated plasma levels of endothelin in patients with sepsis syndrome. Circ Shock 33: 222-227, 1991.

62. Werner HA, Herbertson MJ, Walley KR. Amrinone increases ventricular contractility and diastolic compliance in endotoxemia. Am J Respir Crit Care Med 152: 496-503, 1995.

63. Winegrad S. Endothelial cell regulation of contractility of the heart. Annu Rev Physiol 59: 505-525, 1997.

64. Yanagisawa M, Inoue A, Ishikawa T, Kasuya Y, Kimura S, Kumagaye S, Nakajima K, Watanabe TX, Sakakibara S, Goto K, Masaki T. Primary structure, synthesis, and biological activity of rat endothelin, an endothelium-derived vasoconstrictor peptide. Proc Natl Acad Sci USA 85: 6964-6967, 1988.

65. Yang HT, Sakurai K, Sugawara H, Watanabe T, Norota I, Endoh M. Role of $\mathrm{Na}^{+} / \mathrm{Ca}^{2+}$ exchange in endothelin-1-induced increases in $\mathrm{Ca}^{2+}$ transient and contractility in rabbit ventricular myocytes: pharmacological analysis with KB-R7943. Br J Pharmacol 126: 1785-1795, 1999. 